\title{
Beach Tourism Destinations Promotion Strategy Tthrough Social Media Influencers in Bulukumba Regency
}

\author{
Asmawaty $^{1}$ \\ Corresponding Email: asmawattys@gmail.com \\ ${ }^{1}$ Makassar Tourism Polytechnic, Indonesia
}

\begin{abstract}
The purpose of this study is to determine the strategy of influencers in attracting tourist visits to Bulukumba Regency. The method used in this research is a qualitative approach. The subjects in this study were the people around the tourist attraction, tourists and the Bulukumba Regency Tourism Office. The research instrument is Observation, Interview and Documentation. The results of this study show. Influencer Marketing is one of the marketing strategies by using efficient social media to promote a product or service offered by the industry. Not only that, using Influencer Marketing can significantly cut costs used for promotions.
\end{abstract}

Keywords: Influencers, Travel Destinations, Beaches, Social Media

Received: October 12, 2021

Revised: November 10, 2021

Accepted: November 14, 2021

\section{Introduction}

Tourism should be able to provide opportunities for all Indonesian people to try and work. Tourist visits to an area should provide the maximum benefit for improving the welfare of the community. Thus tourism is able to provide a major contribution to poverty in various areas that are poor in economic potential other than natural and cultural potential for tourism purposes (Nirwandar, 2011).

According to Fathun (2018), tourism is one of the vital objects in developing Indonesia. This is based on the natural beauty that is owned by Indonesia along with the diversity of culture, ethnicity, language, culinary crafts, which are the foundation for building Indonesia in the creative economy. Why is it said to be creative because this is related to the innovations created by a number of regions to produce economic coffers without having to spend a lot of money. In the sense that this is related to the level of creativity in utilizing culture, culinary, regional conditions and other fields as objects of attraction for foreign tourists

Meanwhile, according to (Brahmanto, 2015) tourism is "a journey from one place to another, temporary in nature, carried out individually or in groups, in an effort to find balance or harmony and happiness.

with the environment. In addition, tourism is divided into several types, namely "(1) tourism to enjoy the trip (pleasure tourism); (2) tourism for recreation (recreation tourism); (3) tourism for culture (culture tourism); (4) tourism for sports (sport tourism); (5) tourism for business affairs (business tourism); and (6) tourism for convention (convention tourism).

In increasing regional income, the government needs to develop and facilitate all tourism activities so that the tourism sector can contribute to regional economic development. As a source of regional income, tourism certainly cannot be separated from tourist visits. The progress of the tourism sector is highly dependent on the number of tourists visiting. So that more tourists visit, it must be supported by attractive tourist destinations with supporting 
facilities for the convenience of tourists. In other words, in increasing tourist visits, there needs to be a strategy in tourism development.

Strategies to attract more tourists or if there has been an accumulation of tourists there must be a strategy to make tourist trips evenly distributed throughout all tourist destinations. However, to make a strategy and policy, it is necessary to have just and date information that is important about the tourist market, so that the strategy designed will be right on target. The strategy in question is a strategy that can be used.

By tourism destination managers for product development or strategies that will be used as policies by local governments (Susanto et al., 2021). The decision to visit is also influenced by personal characteristics, which are included in this category are age and life cycle, occupation and economy, personality and self-concept, and lifestyle and values. Because some of these characteristics have a direct impact on tourist behavior, this is very important for marketers in approaching tourists. There are four key psychological processes namely, motivation, separation, learning and memory which are the basis for influencing tourist responses (Suherlan, 2014).

In the information age is growing rapidly in Indonesia. Information is needed by everyone to know the developments they are following. Information is a daily need for all people. Through information media, a message can be conveyed properly if the media is made right to the target and the information conveyed is useful for the maker and the target. The presence of multimedia more or less stimulates serious thinking and is also a complementary tool for social life, along with the development of an all-digital era. The role of information media is one of the strategies in increasing tourism promotion in improving facilities and handling tourism objects (Nirmala, et al., 2019).

Development of programs related to tourism promotion in improving facilities and better maintenance of tourism objects. Good facilities will affect tourist visits to tourism objects (Pertiwi 2014). Including this digitalization era, community trends change very quickly due to easy access to find information (Nirmala et al., 2019). The field of tourism as one of the industries that is developing rapidly is of course constantly changing following the ongoing trends. The tourism sector needs to adapt quickly to the environment and intense competition. Digitization of tourism is the best step to survive in the rigors of technological evolution and informationation where the physical dimensions and government of tourism enter the next level (digitalization) so as to achieve a new generation that is more modern in accordance with the times.

The use of media is one of the primary needs for everyone. This is due to the need for information, entertainment, education, access to knowledge that can be done from different parts of the world. Technological advances make the media as devices produced by industry so that we know the term "World in Hand".

The ease of communication is one of the reasons the media is the main tool for the public in obtaining the right information. In Rulli Nasrulah introduced the term "world without secret" that the presence of new media makes information easy to find and open (Marta 2020). Today, new media is not only used in the fields of journalism, politics, marketing, but plays has penetrated into the world of public relations. Public relations has a variety of publics, so the content or public relations also varies. Practitioners must issue publications through brochures, leaflets or magazines to the public, which must be distributed one by one. The presence of social media is the latest innovation in activities including government media. Information that is broadcast through social media can directly reach a larger public (Irsat, 2018). 
Social media is one of the communication media that is carried out in 2 (two) directions where this communication can be established through writings, photos or images, visual and audio videos that can be channeled through the internet. Social Media can also be said as a form of an internet-based application. Social media can be said to be a real form of a new media which is based on the progress of a communication technology (Purwanto et al., 2020). This is supported by various factors of information and communication technology (Information and Communication Technology).

Social media, which we understand as a new form of communication in online media, is supported by various software applications and causes various interactions between millions of users. The social media that we use have advantages in their various abilities to communicate interactive two-way information, and help users to access various kinds of information (Subiakto, 2019).

With the right social media strategy and good strategy execution, the Ministry of Tourism and Creative Economy / Tourism and Creative Economy Agency and the tourism industry in Indonesia can increase awareness and positive image of national tourism so that the number of visits and movements of foreign and domestic tourists will increase. Social media influencers exert broad influence on social media users, by inserting a number of new messages or popularizing certain issues. This makes the audience more aware of a particular issue in society, including the topic of self-confidence or the ideal body shape for women (Christa, 2015).

The existence of a discussion about self-confidence or ideal body shape is a serious and important discourse for modern society. So that the activity of disseminating information about it becomes important for the audience, therefore the role of social media Influencers is important to know, especially in the messages presented on social media.

Currently, users of information technology, especially the internet, from year to year are always increasing. The UI Communications Study Center released a press release on the results of the survey of internet user profiles in Indonesia, the results of this survey are the result of collaboration with APJII which is a source of information about current internet user data in Indonesia. The survey states that the number of internet users in Indonesia has reached 88.1 million users. The high number of internet users makes Indonesia a potential market for online business activities

Manap \& Adzharudin (2013) are emphasizing the role of the Internet to develop tourist destinations, the same opinion is also expressed by Hanan \& Putit (2013) where the contribution of social media as a driving factor to promote destinations. Both of their arguments show that the tourism industry and the Internet provide space to make travel decisions for tourists. Therefore, it is not surprising that the internet has fundamentally changed the way in which travel information is searched and the process of determining tourist destinations (Morosan \& Jeong, 2008).

One of the newly designed strategies in the tourism marketing strategy is the endorser strategy as a medium to promote or introduce Indonesian tourism to the wider community. Today's society has a very strong and extensive communication network and is increasingly critical of information making it difficult to get their attention (De Mooij \& Hofstede, 2011). Technological advances also make endorsers have a shift in their broadcast media. The presence of social media as a means of modern communication from society forces marketers to prepare new strategies to be able to communicate their products. There is a new trend to commercialize personal life in the community, making endorser patterns also change. It is estimated that 83 percent of consumers will consume based on recommendations from friends, 
family, and encouragement from endorsements compared to television advertising in the 2000s. Seeing this trend, marketers can create new effective marketing creations at much lower costs. Recommendations from friends and family can be obtained through social media.

The use of internet-based social media as a tourism communication medium is more flexible and profitable, because the use of media like this is considered easier, has a broad reach, and is cost-effective in communicating tourism. Social media is an internet-based media that makes it easy and even allows users to easily participate, create and share their experiences and information. In addition to Facebook, Twitter, Pinterest, LinkedIn, and Path, which are some of the favorite social media in Indonesian society, one of the most popular social media is social media growing fast is Instagram.

In a digital era like today, marketing strategies have also utilized digital technology with the use of social media as marketing tools. Social media has become part of people's daily lives as a medium of communication. There are many advantages to doing promotions on social media, which are cost-effective and can reach potential consumers who are widely spread throughout the world. The current phenomenon, to increase marketing on social media, companies have started to use influencers as their marketing strategy. Influencer (n) in English means someone who can influence. An influencer is someone who has the power to influence others to make purchasing decisions based on previous experience. Influencers are used by a brand to convey the goals of the brand to certain target consumers. Those who become influencers can be artists or even celebrities who are idols of their followers on social media. Seeing this, it is necessary to do research to analyze the roles and strategies that can be done for promotion by utilizing influencers on social media. The chosen social media is Instagram, where Instagram is the number 4 most active social media platform in Indonesia and Indonesia is the country with the most Instagram users in Asia Pacific. Instagram is also a social media platform that is widely used for business events with influencers as an attraction. The purpose of this study is to change the perspective of visual communication designers to be more aware of social media marketing strategies.

The content created by these influencers can be through Instagram, YouTube, Twitter, or Facebook. Instagram, which was originally a social network for sharing photos and videos, is now also used to market products, both by business actors and influencers. Instagram's high activity, which is 1 billion per month, and there are more than 500 million Instagram users opening one profile at least every day, can help grow business through profiles and content created.

Several studies related to social media have been carried out, such as the impact of using Instagram as a product marketing medium, as well as the impact of uploads on Instagram on viewers' perceptions. Research related to influencers is also widely carried out, such as the influence of influencers on interest and product purchase decisions (Ewers, 2017). The impact of marketing through influencers on Instagram on the number of followers and the trust gained by followers, (Eriksson \& Hansson, 2016), as well as the impact of influencers on Instagram on viewers' decisions to travel have also been investigated. Research related to the effect of advertising on Instagram on the effectiveness of marketing strategies (Indrawati et al., 2017) and the effect of advertising on Instagram on increasing product sales were also taken as a reference source. From some of these studies, further research will be carried out by analyzing the influence of influencers and advertising on Instagram on tourism marketing.

The previous research conducted by Puji Sarjono \& Triyono (2017) also shows that Instagram is useful for promoting the city brand of Pekalongan city as a city of Batik. The form of a city brand that is carried out is through Instagram social media using the @instapekalongan

Copyright ( 2021 , International Journal Papier Public Review, Under the license CC BY-SA 4.0 DOI: https://doi.org/10.47667/ijppr.v2i4.117 
account, with attribute criteria, messages, differentiation and ambassadors displayed through photo and video displays. In this way the city of Pekalongan is able to attract followers to see there is even a desire to come and live in the city of Pekalongan. From this phenomenon, it means that all have broad opportunities to communicate and promote tourist attractions through Instagram with supporting features that can be utilized optimally.

Influencers represent a new kind of freedom, third parties shaping audience behavior through blogs, tweets, and other uses of social media (Freberg et al., 2011). Influencers create content to market a particular brand with the aim of gaining followers and recognition for that brand. Nowadays influencers are considered a phenomenon. In some studies, influencers are considered to be able to increase engagement between consumers and the products being marketed. Influencers with a large number of followers will have a large number of likes. Consumer intentions to buy products will be high if the product is marketed by influencers, but will be higher if the product is marketed by celebrities compared to micro-celebrities (Ewers, 2017). Consumer buying intentions are also influenced by credible and attractive influencers in marketing products (Eriksson \& Hansson, 2016). In addition to influencing consumers' purchase intentions, the presence of influencers also influences changes in the concept of social reality.

Currently digital marketing or better known as digital marketing is the most popular marketing strategy. Consumers tend to do research in online searches before deciding to buy a product. Of a number of digital marketing techniques, influencer marketing is also included as a promotional method that is considered effective. This technique involves the services of influencers to promote a business through social media. Instagram, Facebook, Youtube, Twitter and so on are gathering places for influencers.

This marketing method has become increasingly popular in recent years. Influencer marketing is proven to be effective in building brand awareness and consumer loyalty to a business. A celebgram or youtuber is even able to earn fantastic income just from the content they present on social media.

This strategy is apparently also being implemented by the Ministry of Tourism and Creative Economy (Kemenparekraf). The ministry, which is now led by the former NET TV media boss, Wishnutama Kasubandio, has implemented various strategies to attract foreign tourists to visit tourist destinations in Indonesia.

It is undeniable that conventional marketing through brochures, newspapers, radio and the like has begun to be abandoned by business people. According to data released by Gushclod, the amount of advertising spending in the Asia Pacific region has increased significantly. Influencers are considered effective in influencing consumer behavior to determine product purchases in the form of goods or services. Social media has proven to be a powerful tool for selling. Gushcloud data shows that the conversion rate of purchases from social media is quite high. Moreover, the costs incurred to use their services are relatively affordable compared to marketing their products in newspapers and television. Promotional services offered by Selebgram, for example, range from Rp. 100 thousand. While Youtubers range from Rp. 500 thousand. Much cheaper than marketing products in newspapers which can reach Rp. 20 million if the product is displayed on the main page.

Unfortunately, the primacy of social media through influencers has not been fully utilized and has become a serious concern for some public relations practitioners, as well as government public relations. Practitioners still use conventional media as the main media to socialize, promote policies, activities, programs that will or have been implemented (Rahmawan et al., 
2017). This condition is certainly a big problem, considering that the current public are internet users who are spread throughout Indonesia. This condition also occurs in government public relations, especially in Bulukumba Regency. One of the Influencer's activities is promotion, in this case it must promote tourism potential that is spread in Bulukumba Regency which is very rich in its superior marine tourism destinations, it is very unfortunate if the promotion is carried out by certain parties who do not have high awareness of this potential.

With the promotion of Influencers through social media, there will be more Bulukumba people, so that more and more people want to visit and do tourism activities in Bulukumba Regency. This of course can have a positive impact on tourism in Bulukumba Regency. With many tourists visiting Bulukumba Regency, automatically local regional income can increase the economic income of the community. The purpose of this study is to determine the strategy of influencers in attracting tourist visits in Bulukumba Regency.

\section{Methods}

The method used in this research is a qualitative approach. The subjects in this study were the people around the tourist attraction, tourists and the Bulukumba Regency Tourism Office. In order to dive to a deep insight, the study thus used instrument like Observation, Interview and Documentation. The study analyzes the data through data reduction, data cluster, conclusion making and data display.

\section{Results and discussion}

\section{Promotion of beach tourism destinations in Bulukumba Regency}

One of the best strategies that can be used to bring in potential tourists is to use the services of Influencer marketing. Carrying out marketing using social media using the mass owned by an influencer, an influencer can generate more value from better product brands and at a cheaper price than using brand endorsers or public figures who are already among the top artists.

An influencer is universally selected based on his expertise, ability, level of popularity, or reputation. By using this method, it is hoped that a certain industry or brand will be more loyal to the influencer by building a deeper bond and not only explaining about the product, but also providing data and special facilities for new products and behind-the-scenes processes. of the brand to be promoted. Things that need to be considered when selecting influencers must return to the concept of segmentation, targeting and positioning of the desired target consumer because this will affect the number of followers and the level of involvement of the platform to be used, the platform which is defined as sometimes someone influencers can produce communities that can share their impressions of the products to be marketed, in some cases, influencers with a small number of followers but have a large involvement can be more efficient in influencing the level of product sales to consumers.

The popularity position of social media also influences the level of popularity of an influencer and increases the number of these influencers, so that it will indirectly reach a wider level of consumers who are familiar with social media, based on the number of followers, influencers can be divided into four groups, namely Mega- Influencers, Macro- Influencers, MicroInfluencers, and Nano Influencers.

In terms of product promotion, the use of influencers is an effort to help disseminate data and influence / persuade to be willing to accept, buy and be loyal to the products offered. This is in line with the definition of promotion for Tjiptono (2000). Digital influencers can help spread information and influence their followers with the stories they share on their Instagram accounts. The purpose of using digital marketing promotion is in line with the promotional 
objectives by Kotler (2002) starting from distributing data about certain products, forming an image, increasing sales let alone changing consumer attitudes.

Of course, there are several criteria in selecting the right influencer for the promotion of a product. The number of followers is not solely a major consideration. Nurhasanah, aliyah patwa, Muhammad darsal, Irish bella and Amar zoni are some people who use digital marketing to promote marine tourism destinations in Bulukumba Regency, considering that all of these people have a large number of followers and can indicate If the content posted is of good quality, it is also a must to see if the uploaded photos match the brand or product values. Not only that, the aspect that is considered is the engagement of each image upload. A good influencer is having content that is talked about / invites a lot of comments. One of the markers of engagement from a digital influencer account is the number of likes for an article, at least $20 \%$ of the total followers.

Digital Influencers Instagram can be seen from 2 things, namely in terms of quantity and in terms of quality. In terms of quantity, it can be seen from the number of followers, the number of likes on the article. and how many re-posts. On the other hand, in terms of quality, seen from the quality of content and engagement, it is interaction with fellow Instagram users. Engagement can be seen from comments, reactions to comments from articles. IG account @_irishbella_. @ammarzoni, @aaliyahpatwa, @mhmdarsal13, @nhrnurhasanah, @visitsulsel.id, and @dispar.bulukumba are considered suitable to be digital influencers because of their consistency in raising tourism topics. The number of followers they have is mostly followers from their web, which can be thought of as loyal followers. The increased content is in accordance with the tourism potential of the Bulukumba district, as well as its lifestyle which is considered cool and exciting.

The ability to influence like a friend is the credibility a digital influencer looks for. This is what distinguishes it from promotion through conventional advertising. Digital influencers are a clear example of the integration of PR (credibility, word of mouth) and marketing (promotion and product information). The role of Digital Influencers in product promotion is considered more effective and effective, as the results of a survey from McKinsey reported in Forbes magazine. The survey shows that digital word of mouth activity can drive sales 2 times greater than from advertising, and has a retention rate or the proportion of consumers who persist in a certain time period of $37 \%$ greater.

Another advantage of doing promotions through influencers on Instagram is also related to the features that Instagram has, such as being able to share to other social media accounts, using hashtags so that posts can be easily searched, also being able to call (tag) friends or other parties relevant to Instagram. product, or pass the product on to certain people.

Based on the explanation above, carrying out product promotions using digital influencers is something that deserves consideration in promotional activities in this digital era, especially for products that have a target audience of millennials, who are very engaged with digital media.

Tourism is indeed a leading sector in Bulukumba and greatly supports the local community's economy. Of the 37 tourist beaches here, the majority are still managed independently by the community. Bulukumba Regency is also famous as a phinisi boat producer area. In fact, this phinisi ship has been recognized as an intangible cultural heritage by UNESCO in December 2017.

According to the Head of the Bulukumba Tourism Office, Muhammad Ali Saleng, the tourism potential in Bulukumba is also very diverse, ranging from mountains, beaches, to underwater 
tourism. To support the progress of the tourism sector, he said, the availability of internet facilities is very much needed.

Let alone the government in an effort to promote, friends from business actors also have a high dependence on the use of internet facilities. Therefore, we really hope that this internet service facility will be improved because it is a basic need in our marketing (interview: Muhammad Ali Saleng, Head of the Bulukumba Regency Tourism Office).

Based on the interview above, it is known that the internet network is very important as a medium for promoting tourist destinations in Bulukumba Regency. The high use of internet facilities is not only in the interest of the Dispar Bulukumba Regency but also for tourism business actors in Bulukumba Regency.

Head of the Bulukumba Regency Communication and Information Office, M Daud Kahal, said that the scope of the internet network in Bulukumba continues to be developed to raise the various cultural and tourism potentials of Bulukumba to be world class.

The opening of tourist attractions is accompanied by strict rules. Keep it open, so the regent's circular letter, including being unable to facilitate activities such as family gatherings, get-togethers, which can cause crowds. In addition, there are officers who were alerted as yesterday from the Indonesian National Police and the Health Office. Dispar has indeed recruited medical personnel, Satpol PP and members of the Transportation Agency. There has also been a decline in visitors to tourist attractions by around 80 percent compared to before Covid (interview: Muhammad Ali Selang, Head of the Bukukumba Tourism Office).

Based on the interview above, it is known that during the Covid-19 pandemic, tourist destinations in Bulukumba district will remain open while still following the health protocol according to the instructions of the Bulukumba Regent. On holidays, especially Eid holidays in several tourist locations, the TNI, Polri, Satpol PP and Health Workers will be alerted. Every tourist who comes is required to wear a mask. Even so, according to the head of the Bulukumba Regency Tourism Office, there was a very significant decrease in the number of tourist visits during the COVID-19 pandemic, reaching $80 \%$.

One of the most visited destinations in Bulukumba district is Tanjung Bira. Although the visitors are not as many as before covid but this can be said to be pretty good. Before the pandemic period, tourist holidays in Tanjung Bira could reach 3 thousand people per day on Saturdays and Sundays. Now it's only half, sometimes not even half. Even though Tanjung Bira is one of the tourist destinations that is the mainstay of PAD for Bulukumba Regency, tourists who come must still comply with the health procedures, so we are both protecting ourselves from the transmission of Covid 19 (interview: Muhammad Ali Saleng, Head of the Bulukumba Regency Tourism Office).

Based on the interview above, it is known that on holidays such as Saturday and Sunday, tourists in Tanjung Bira can reach 3 people, but during the COVID-19 pandemic there was a decrease in the number of visits. In fact, Tanjung Bira is one of the leading destinations for the Bulukumba Regency government as a contributor to PAD from the tourism sector which is quite high.

Bulukumba Regency has quite a lot of tourist destinations, for more details, see the table below:; 
Table 1. potential for marine tourism in Bulukumba Regency

\begin{tabular}{|c|c|c|c|c|c|c|}
\hline No. & DTW name & Main Attraction & $\begin{array}{l}\text { Distance } \\
\text { from } \\
\text { City/District }\end{array}$ & $\begin{array}{l}\text { Already } \\
\text { Managed/Not } \\
\text { yet }\end{array}$ & Manager & Information \\
\hline 1. & Bira Beach & $\begin{array}{l}\text { - Expanse of } \\
\text { white sand } \\
\text { along the } \\
\text { beach } \\
\text { - The beauty of } \\
\text { the sea and } \\
\text { coral reefs } \\
\text { - Clusters of } \\
\text { rocks along } \\
\text { the coast }\end{array}$ & $\begin{array}{l}42 \mathrm{Km} / 1 \\
\text { hour }\end{array}$ & Done & $\begin{array}{l}\text { Local } \\
\text { government } \\
\text { and private }\end{array}$ & $\begin{array}{l}\text { Ssupporting } \\
\text { facilities } \\
\text { infrastructure: and } \\
\text { Hotels, lodging, } \\
\text { food stalls and } \\
\text { entertainment } \\
\text { facilities, sports } \\
\text { facilities, rinse } \\
\text { rooms on the beach, } \\
\text { mosques, meeting } \\
\text { halls / Baruga, } \\
\text { diving, banan boats } \\
\text { and snorkelling, } \\
\text { smooth access and } \\
\text { close to the Fery } \\
\text { port, Bira Pamatata, } \\
\text { Bira Village } \\
\text { Bontobahari } \\
\text { regency }\end{array}$ \\
\hline 2. & $\begin{array}{l}\text { Lemo-Lemo } \\
\text { beach }\end{array}$ & 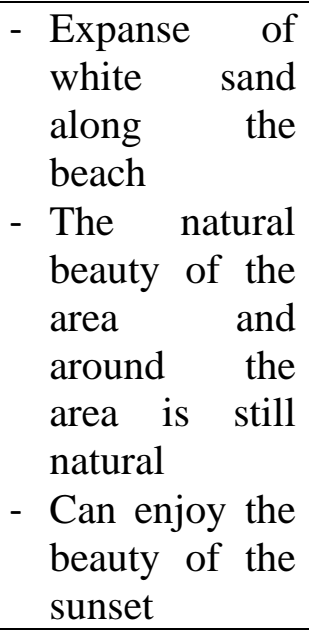 & $\begin{array}{l}33 \mathrm{Km} / 45 \\
\text { Minutes }\end{array}$ & Done & $\begin{array}{l}\text { Local } \\
\text { government } \\
\text { and private }\end{array}$ & $\begin{array}{l}\text { Good access and } \\
\text { lack of facilities / } \\
\text { Tana Lemo village. } \\
\text { Bontobahari } \\
\text { regency }\end{array}$ \\
\hline 3. & $\begin{array}{l}\text { Panrangluhu } \\
\text { beach }\end{array}$ & $\begin{array}{l}\text { - White sand } \\
\text { and coconut } \\
\text { trees along the } \\
\text { coast }\end{array}$ & $\begin{array}{l}39 \mathrm{Km} / 50 \\
\text { Minutes }\end{array}$ & Done & Public & $\begin{array}{l}\text { Good access and } \\
\text { lack of facilities / } \\
\text { Bira. Village }\end{array}$ \\
\hline 4. & $\begin{array}{l}\text { Mandala Ria } \\
\text { Beach }\end{array}$ & $\begin{array}{l}\text { - The natural } \\
\text { beauty of the } \\
\text { area and its } \\
\text { surroundings }\end{array}$ & $\begin{array}{l}38 \mathrm{Km} / 50 \\
\text { minutes }\end{array}$ & Done & Public & $\begin{array}{l}\text { Lack of access and } \\
\text { facilities / Darubia } \\
\text { Village, } \\
\text { Bontobahari } \\
\text { Regency }\end{array}$ \\
\hline
\end{tabular}




\begin{tabular}{|c|c|c|c|c|c|c|}
\hline 5. & $\begin{array}{l}\text { Marumasa } \\
\text { beach }\end{array}$ & - unspoiled area & $\begin{array}{l}39 \mathrm{Km} / 50 \\
\text { minutes }\end{array}$ & Done & Public & $\begin{array}{l}\text { Good access and } \\
\text { lack of facilities / } \\
\text { Darubia Village, } \\
\text { Bontobahari } \\
\text { Regency }\end{array}$ \\
\hline 6. & $\begin{array}{l}\text { Kusuno } \\
\text { beach }\end{array}$ & $\begin{array}{l}\text { - The longest } \\
\text { white sand } \\
\text { beach in } \\
\text { Bulukumba }\end{array}$ & $\begin{array}{l}40 \mathrm{Km} / 50 \\
\text { minutes }\end{array}$ & Done & Public & $\begin{array}{l}\text { Good access and } \\
\text { lack of facilities / } \\
\text { Darubia Village, } \\
\text { Bontobahari } \\
\text { Regency }\end{array}$ \\
\hline 7. & $\begin{array}{l}\text { Samboang } \\
\text { beach }\end{array}$ & $\begin{array}{l}\text { White sand, long } \\
\text { beach kl. } 800 \\
\text { M }\end{array}$ & $\begin{array}{l}40 \mathrm{Km} / 50 \\
\text { minutes }\end{array}$ & Done & Public & $\begin{array}{l}\text { Good access and } \\
\text { lack of facilities / Tri } \\
\text { Tiror Village, } \\
\text { Bontotir Regency }\end{array}$ \\
\hline 8. & $\begin{array}{l}\text { Losiang } \\
\text { beach }\end{array}$ & $\begin{array}{lr}\text { - } \begin{array}{lr}\text { Expanse } \\
\text { white }\end{array} \\
\text { along } \\
\text { beach }\end{array}$ & $\begin{array}{l}40 \mathrm{Km} / 50 \\
\text { minutes }\end{array}$ & Done & Public & $\begin{array}{l}\text { Very smooth access } \\
\text { / Lolisang Village, } \\
\text { Kajang Regency }\end{array}$ \\
\hline 9. & $\begin{array}{l}\text { Merpati } \\
\text { beach }\end{array}$ & $\begin{array}{l}\text { - There is a } \\
\text { location where } \\
\text { the phinisi } \\
\text { boat is made }\end{array}$ & $0 \mathrm{Km}$ & Done & Public & $\begin{array}{l}\text { Very smooth access } \\
\text { / Ujung Bulu } \\
\text { Village, Ujung Bulu } \\
\text { Regency }\end{array}$ \\
\hline 10. & $\begin{array}{l}\text { Phinisi Boat } \\
\text { Building } \\
\text { Beach Area }\end{array}$ & $\begin{array}{lr}\text { - } & \text { Expanse of } \\
\text { white sand } \\
\text { along the } \\
\text { beach }\end{array}$ & $\begin{array}{l}30 \mathrm{~km} / 40 \\
\text { minutes }\end{array}$ & Done & $\begin{array}{l}\text { Local } \\
\text { government } \\
\text { and private }\end{array}$ & $\begin{array}{l}\text { Good access and } \\
\text { lack of facilities / } \\
\text { Bira Village, } \\
\text { Bontobahari } \\
\text { Regency }\end{array}$ \\
\hline
\end{tabular}

Source: observation data results

Based on table 5.1 above, it is known that Bulukumba district has at least 10 marine tourism destinations that are its mainstay, the ten marine tourism destinations are the main attraction for tourists and can provide sufficient choices for tourists who want to enjoy the panorama of the sea/beach in Bulukumba district. On average, these destinations are managed by the government and the private sector as well as the community. The distance from tourist sites from the district capital at the most takes 1 hour drive. Even so, the accessibility to go to every tourist location is very good.

In tourism promotion, of course, the images displayed in videos or photos must look good and attractive, sometimes this can also be a problem because sometimes the uploaded images do not match what is at the tourist location. according to informants;

Related to the discrepancy of images in social media with the reality is that it's just a normal thing, because not all of the photo spots can last long, as for what's uploaded on Instagram and it doesn't match, it's just old photos that show the conditions at that time, not all the photos that were uploaded not appropriate, so in my opinion there is no element of fraud and others (Interview: Disbudpar staff of Bulukumba Regency).

Based on the interview above, it is known that some tourist attractions in Bulukumba Regency sometimes do not match what is displayed on social media posts. This is because some of the 
photos posted are photos when a new tourist attraction is opened or the sophistication of Photoshop application technology in beautifying the appearance of photos, so that existing photos become very beautiful and instagramable. However, this cannot be considered a fraud because, in carrying out promotions, something beautiful should be displayed so that it can attract tourists to visit.

Our goal for the tourism office is to bring in as many people as possible, so the tourism office uses one form of promotion using social media, namely advertising and publicity, one of the right things to do at this time. With the existence of social media which has always been part of the daily activities of almost all people, doing advertisements and publicity on social media is the right thing. Advertising and publication is one form of promotion used by the tourism office of Bulukumba Regency (interview: Bulukumba Dispar Staff).

The role of advertising in service marketing is to build awareness (awareness) of potential buyers or clients or targets for the services or goods offered, to increase consumer knowledge, persuade prospective buyers to want to buy, want to use these services, and to differentiate services from one company to another. another company. Supported by the statement that one of the Public Relations of the Tourism office also said almost the same thing;

Similarly, tourism also requires advertising to the target, buyer or client in its easy language to introduce tourism in Bulukumba Regency. The public must know about all tourism in Bulukumba Regency which is actually not inferior to tourist destinations with other cities/regencies. With this, using advertising on social media is also a very good step to gain more public awareness of tourism in the city itself, namely Bulukumba Regency. In addition, we must introduce to the public that living in urban areas does not mean that we cannot live a relaxed and relaxed life and that we do not always have to breathe and eat the smoke of the non-stop air. Because Bulukumba Regency also has its own tourism that is able to pamper the people of Bulukumba Regency or other people outside the city (Interview: Public Relations Dispar Bulukumba Regency).

In this case the author can see that indeed the form of promotion, namely advertising, dominates as one of the tourism promotions in Bulukumba Regency using social media. Using social media as a means to create advertisements makes it possible to better introduce the tourism sector in Bulukumba Regency to the wider community. Not far from the statement of his two colleagues, one of the employees in the promotion admin field that:

The use of social media as a promotional media is very necessary in this millennial era, along with the development of the era social media has become close to the community so that it is the right thing to use social media as a promotional tool in the form of advertisements and publications carried out on social media (interview: Bulukumba dispar promotion staff).

Using social media as a promotional tool and media to do advertising and publicity to the community is indeed very necessary to attract public interest in tourism in Bulukumba Regency besides being cheap, social media is also a medium that is becoming an idol in our society, this is what the Office sees Tourism as an activist in the tourism sector, of course. Social media has become the media of choice as a medium for tourism promotion in Bulukumba Regency and is a medium that is able to do that. In addition, there are obstacles in using social media as a medium for tourism promotion, according to informants; 


\begin{abstract}
Barriers or obstacles in using social media as one of the promotional media are unavoidable from obstacles, for example, from people posting things that are against us (the tourism office) and also negative things on social media about Bulukumba Regency. Other obstacles also come from us as people who run social media, for example, our mentality must be prepared to be active on social media, and we also have to become media literate (interview: Bulukumba Dispar Promotion field).
\end{abstract}

From the interview above, it can be concluded that the obstacles that occur can categorized into two barriers, namely internal and external, namely internal barriers

dam outside obstacles. Internal barriers are from workers in the tourism office who experience their own problems, for example mental which must be improved and so on. Then the obstacles from outside in the form of public posts on social media which are inversely proportional to the Tourism Office.

People, especially in Bulukumba Regency, are not all aware of or sensitive to their own environment, so negative things are displayed on social media which are contrary to the Tourism Office which of course posts about the beauty of Tourism itself. This will affect the content of social media and the quality as a means of promoting tourism in Bulukumba Regency.

Wahdah often goes on vacation to beach tourism in the surrounding Bulukumba Regency more than eight times, he knows about this tour through various social media, such as Instagram, Facebook, Google, he has even seen it from Trans TV. Wahdah's purpose in coming to this tourist location is for a vacation, he is very interested in returning and returning to tourist sites because he thinks this beach tourism is very interesting, comfortable, quiet, affordable, and the cost is quite cheap besides that because Bulukumba district has a pretty coastline. so that tourists have many choices of beach tourist destinations, but the most popular are Tanjung Bira and Apparalang beaches. However, according to Wahdah, the promotions carried out must be further improved, such as always updating on social media related to tourism developments. And Regarding the discrepancy between posting photo spots on social media accounts with the reality at the location, he didn't mind it. According to the Bulukumba Dispar, the promotion carried out by the manager is quite good, there is no element of fraud at all because the manager always uploads images according to the circumstances at that time. If at this time the image is no longer there, it is natural, because it has been quite a while, so there is a possibility that the photo spots are damaged. And for the facilities to be further improved so that visitors who come can be more comfortable because there is no heavy food in the tourist area

\title{
Conclusion
}

Looking at the marketing capabilities of the modern era which is again dominated by marketing through social media which is accessed through individual features. Influencer Marketing is one of the marketing strategies by using efficient social media to promote a product or service offered by the industry. Not only that, using Influencer Marketing can significantly cut costs used for promotions. Meanwhile, for other purposes, the implementation of Influencer Marketing is very suitable to be applied to improve the brand image (Brand Image) efficiently and increase the Brand Awareness of consumers towards the brand.

\section{References}

Brahmanto, E. (2015). Magnet Paket Wisata Dalam Menarik Kunjungan Wisatawan Asing Berkunjung Ke Yogyakarta. Media Wisata, 13(2). 
Christa, V. (2015). Peran strategic planner dalam social media marketing agency di pt bina blog indonesia [Doctoral dissertation, Universitas Multimedia Nusantara]. Universitas Multimedia Nusantara Knowledge Center. https://kc.umn.ac.id/3793/

De Mooij, M., \& Hofstede, G. (2011). Cross-cultural consumer behavior: A review of research findings. Journal of international consumer marketing, 23(3-4), 181-192.

Eriksson, E., \& Hansson, C. (2016). Fashion Brands and Engagement on Instagram: How can fashion brands apply content marketing on Instagram to engage Millennials and increase brand equity? [Thesis, Högskolan i Halmstad]. Research Publication. http://hh.diva-portal.org/smash/record.jsf?pid=diva2\%3A943429\&dswid=3787

Ewers, N. L. (2017). \# sponsored-Influencer Marketing on Instagram: An Analysis of the Effects of Sponsorship Disclosure, Product Placement, Type of Influencer and their Interplay on Consumer Responses [Master's thesis, University of Twente]. University of Twente Student Theses. https://essay.utwente.n1/72442/

Fathun, L. M. (2018). "Pariwisata Di Era Ekonomi Digital" Sebuah Implementasi Pilar Kebijakan Poros Maritim Di Era Jokowi Dalam Konteks Paradiplomacy. Jurnal Dinamika Ekonomi Pembangunan, 1(2), 56-70.

Freberg, K., Graham, K., McGaughey, K., \& Freberg, L. A. (2011). Who are the social media influencers? A study of public perceptions of personality. Public relations review, 37(1), 90-92.

Hanan, H., \& Putit, N. (2013). Express marketing of tourism destinations using Instagram in social media networking. Hospitality and tourism: Synergizing creativity and innovation in research, 471.

Indrawati, K. A. P., Sudiarta, I. N., \& Suardana, I. W. (2017). The effectiveness of facebook and instagram social media ads as one of the marketing strategies at Bali's Krisna Souvenirs. Tourism Analysis Journal, 2.

Irsat, (2018). Peran Modal Dalam Pemasaran Politik Syamsari Kitta Dan Achmad Daeng Se're Dalam Pemilihan Bupati Dan Wakil Bupati Kabupaten Takalar Tahun 2017 [Thesis, Universitas Muhammadiyah Yogyakarta]. UMY Research Repository. http://repository.umy.ac.id/handle/123456789/25401?show=full

Kotler, P. (2002). Manajemen Pemasaran edisi milenium. Jakarta: Prenhallindo.

Manap, K. A., \& Adzharudin, N. A. (2013, January). The role of user generated content (UGC) in social media for tourism sector. In The 2013 WEI international academic conference proceedings (pp. 52-58).

Marta, R. (2020). Peran Media Sosial Dalam Mempromosikan Pariwisata Sumatera Barat. Jurnal Ranah Komunikasi (JRK), 3(2), 102-112.

Morosan, C., \& Jeong, M. (2008). The role of the internet in the process of travel information search. Information Technology in Hospitality, 5(1), 13-23.

Nirmala, B. M. S., Suardika, I. G., \& Ardiyasa, I. W. (2019). Analisis Usabilitas Aplikasi Mobile eTourism Objek Wisata di Bali Berbasis Location Based Services. EXPLORE, 9(1), 67-74.

Nirwandar, S. (2011). Pembangunan sektor pariwisata di era otonomi daerah. Diakses pada, 24. 
Puji Sarjono, R., \& Triyono, A. (2017). Media Sosial Dan City Branding (City Branding Pekalongan Green City Melalui Media Sosial Instagram) [Doctoral dissertation, Universitas Muhammadiyah Surakarta]. UMS Institutional Repository. http://eprints.ums.ac.id/57193/

Purwanto, N. H., \& Raharja, S. A. S. (2020). Bauran Pemasaran dan Perilaku Pengunjung Wisata Minat Khusus di Objek Wisata Kali Suci Caving dan Tubing. Jurnal Ilmu Lingkungan, 18(3), 467-475.

Rahmawan, D., Mahameruaji, J. N., \& Hafiar, H. (2017). Peran Vlogger Sebagai Online Inflluencer dalam Industri Media Digital di Indonesia. Promedia (Public Relation Dan Media Komunikasi), 3(2)..

Subiakto, M. F. (2019, June 12). Peran sosial media dalam mendukung kinerja perusahaan: Pendekatan orientasi kewirausahaan. https://doi.org/10.31227/osf.io/wq63h

Suherlan, A. (2014). Analisis karakteristik, perilaku, dan motivasi perjalanan wisatawan asal sulawesi utara ke Jakarta. Esensi: Jurnal Bisnis dan Manajemen, 4(3).

Susanto, E., \& Hadian, M. S. D. (2021). Profile Wisatawan Nusantara Taman Nasional Gunung Gede Pangrango. Pusaka: Journal of Tourism, Hospitality, Travel and Business Event, 3(1), 11-17.Tjiptono, Fandi \& Anastasia, Diana, (2000). Prinsip \& Dinamika Pemasaran,.J\&J learning: Yogyakarta. 